\title{
Helicobacter pylori infection and antioxidants can modulate the genotoxic effects of heterocyclic amines in gastric mucosa cells
}

\author{
Tomasz Poplawski $\cdot$ Cezary Chojnacki • \\ Anna Czubatka · Grazyna Klupinska • \\ Jan Chojnacki $\cdot$ Janusz Blasiak
}

Received: 27 July 2012/ Accepted: 30 April 2013/Published online: 10 May 2013

(c) The Author(s) 2013. This article is published with open access at Springerlink.com

\begin{abstract}
Helicobacter pylori (H. pylori) infection plays an important role in gastric carcinogenesis. This bacterium may induce cancer transformation and change the susceptibility of gastric mucosa cells to various exogenous dietary irritants. The aim of the study was to evaluate the influence of H. pylori infection on the reaction of the stomach cells to a genotoxic effect of heterocyclic amines (HCAs). These wellknown mutagens are formed during cooking of protein-rich foods, primarily meat. Taking into account that persons consuming a mixed-western diet are exposed to these compound nearly an entire lifetime and more than half of human population is infected with $H$. pylori, it is important to assess the combined effect of $H$. pylori infection and HCAs in the context of DNA damage in gastric mucosa cells, which is a prerequisite to cancer transformation. We employed 2-amino-3-methylimidazo[4,5-f]quinoline (IQ), 2-amino3,8-dimethyl-imidazo[4,5-f]quinoxaline (MeIQx) and 2-amino-1-methyl-6-phenylimidazo[4,5-b]pyridine (PhIP) because these substances are present in a great amount in cooked and fried meat. Using alkaline comet assay, we showed that the extent of the DNA damage induced by HCAs was significantly higher in $H$. pylori infected gastric mucosa cells than in non-infected counterparts. We did not observed any difference in the efficiency of repair of DNA lesions induced by HCAs in both type of cells. Vitamin $\mathrm{C}$ reduced the genotoxic effects of HCAs in H. pylori infected and
\end{abstract}

T. Poplawski $(\bowtie) \cdot$ A. Czubatka $\cdot$ J. Blasiak

Department of Molecular Genetics, University of Lodz,

Lodz, Poland

e-mail: tplas@biol.uni.lodz.pl;

tomasz.poplawski@biol.uni.lodz.pl

C. Chojnacki · G. Klupinska - J. Chojnacki

Department of Gastroenterology and Internal Diseases,

Medical University, Lodz, Poland non-infected gastric mucosa cells. Melatonin more effectively decreased DNA damage caused by HCAs in H. pylori infected gastric mucosa cells as compared with control. Our results suggest that $H$. pylori infection may influence the susceptibility of gastric mucosa cells to HCAs and dietary antioxidative substances, including vitamin $\mathrm{C}$ and melatonin may inhibit the genotoxic effects of HCAs on gastric mucosa cells and may reduce the risk of carcinogenesis caused by food borne mutagens and $H$. pylori infection.

Keywords Helicobacter pylori - DNA damage . DNA repair $\cdot$ PhIP $\cdot$ MeIQx $\cdot$ IQ $\cdot$ Melatonin .

Vitamin $\mathrm{C} \cdot$ Heterocyclic amines

\section{Introduction}

Helicobacter pylori (H. pylori) is a gram-negative, spiralshaped bacterium that colonize the stomach in more than half of the world population. This bacterium has been classified as a definite carcinogen for gastric cancer by the International Center for Cancer Research on the basis of numerous epidemiological studies [1]. The mechanism through which $H$. pylori exerts its carcinogenic effect is primarily associated with the expression of the CagA protein. It was reported that CagA-negative $H$. pylori strains could also initiate cancer transformation, but the mechanisms of carcinogenesis in this case is associated with chronic gastritis. In this inflammatory condition the immune cells try to kill bacterial cells and synthesize large amounts of free radicals and aldehydes and gastric cells are exposed to these radicals, gastric juice, $N$-nitroso compounds, which are thought to play a secondary, after CagA, role in the development of gastric cancer associated with H. pylori infection [2]. 
Helicobacter pylori could also initiate cancerogenesis indirectly by disturbing normal gastric cells metabolism and in consequence sensitize them to dietary mutagens. We showed previously that $H$. pylori infection can modulate the susceptibility of gastric mucosa cells to $N$-methyl- $N$ 'nitro- $N$-nitrosoguanidine (MNNG), considered as a dietary mutagen and vitamin $\mathrm{C}$ and melatonin reduced the genotoxic effect of MNNG [3]. These antioxidant substances are able to scavenge free radicals and prevent the formation of nitrosamines. However in individuals $H$. pylori infected have been observed reduced levels of antioxidant compounds, such as vitamin $\mathrm{C}$ and increased ROS activity. This could be main reason for stomach diseases and gastric carcinoma [4]. Another group of mutagens presented in food are heterocyclic amines (HCAs). HCAs are formed by food processing. This group of chemicals is of a special significance, because HCAs may directly interact with DNA and form mutagenic adducts [5]. HCAs are present mainly in high temperature-processed meat and fish [6]. They arise as a product of protein pyrolysis or the Maillard reaction. To date $22 \mathrm{HCAs}$ have been found in the pyrolysates of amino acids and proteins, they were divided depending on their chemical structure into two groups, IQ type and non-IQ type. IQ type includes aminoimidazoles, such as 2-amino-3-methylimidazo[4,5-f]-quinoline (IQ), 2-amino-3,8-dimethylimidazo [4,5-f]quinoxaline (MeIQx) and 2-amino-1-methyl-6-phenylimidazo[4,5-b]pyridine (PhIP), and non-IQ type includes pyridoindoles and dipyridoimidazoles, such as 3-amino-1,4-dimethyl- 5H-pyrido[4,3-b]indole (Trp-P-1) and 2-amino-6- methyldipyrido[1,2-a:3', $2^{\prime}$-d] imidazole (Glu-P-1) [5, 6]. HCAs of IQ type are abundant in thermally prepared meats. The degradation of HCAs in humans is initiated by the reactions of $\mathrm{N}$-oxidation, which are catalyzed mainly by the cytochrome P-450 enzymes [7]. The next step involves an enzymatic esterification by acetyltransferases or sulfotransferases to produce reactive nitrenium ions, which can form covalent bonds with DNA mainly at the N2 and C8 positions of guanine, and, when not repaired, cause mutations. DNA adducts can be also formed by HCAs without any enzymatic activation [8]. After the metabolic activation of HCA's, their metabolites are capable of oxidative DNA damage. HCA's can also induced DNA strand breaks. According to their mutagenic nature it is important to assess the combined effect of $H$. pylori infection and HCAs in the context of DNA damage in gastric mucosa cells, which is a prerequisite to cancer transformation. In the present work we evaluated the influence of $H$. pylori infection on the susceptibility of gastric mucosa cells to the DNAdamaging effect of HCAs. We chose IQ, PhIP and MelQx as representative HCAs, because they are present in a relatively high amount in cooked and fried meat and fish [9, 10]. In addition, we checked the protective potential of vitamin $\mathrm{C}$ and melatonin against the genotoxic action of HCAs in gastric mucosa cells. We also assessed the ability of infected and non- infected GMCs to repair DNA damage, so in general, the aim of the study was to evaluate the influence of $H$. pylori infection on the reaction of the stomach cells to a genotoxic effect of HCAs.

\section{Materials and methods}

\section{Chemicals}

HCAs, IQ (2-amino-3-methylimidazo[4,5-f]quinoline), MeIQx (2-amino-3,8-dimethyl-imidazo[4,5-f]quinoxaline) and PhIP (2-amino-1-methyl-6-phenylimidazo[4,5-b]pyridine were purchased from Toronto Research Chemicals (Toronto, Canada) and dissolved in dimethyl sulfoxide (DMSO, Sigma Aldrich, St. Louis, USA). Proteinase K, collagenase, low-melting and normal-melting point agarose, phosphate buffered saline (PBS), Hanks' balanced salt solution (HBSS), Tris and EDTA were purchased from Sigma Chemicals (St. Louis, MO, USA). All remaining chemicals were of the highest commercial grade available.

\section{Patients}

Forty patients of Department of Gastroenterology and Internal Diseases, Medical University of Lodz, Lodz, Poland were studied. They underwent endoscopic examination due to gastric complains, they reported. All patients suffered from dyspeptic symptoms-mostly epigastric pains before and between meals. We excluded subjects with organic changes, deep grade of gastritis, any organic disease, neuropsychiatric disorders, a past history of surgical treatment, another functional disease of alimentary tract, particularly irritable bowel syndrome, allergy, food intolerance, non-steroidal and inflammatory drugs therapy. To avoid any potential influence of confounding factors we also excluded subjects with smoking and abuse alcohol history. There was no difference between gender in both groups. 17 of them, aged from 18 to 63 , median 44 years, were $H$. pylori infected as confirmed by ${ }^{13} \mathrm{C}$-urea breath test. A value of over $3 \%$ in this test was considered to indicate $H$. pylori infection. Remaining 23 patients (25-65 years, median 47 years) were controls. The study was approved by the Ethics Committee of the Medical University of Lodz and each subject gave a written consent.

\section{Cell preparation}

Human gastric mucosa cells were isolated from tissue sample obtained during upper digestive endoscopy from the greater curvature of the upper corpus and the antrum of 
the stomach of each individual. Tissue samples were immediately transported to the laboratory in an ice cold HBSS. The samples were then incubated for $1 \mathrm{~h}$ at $37^{\circ} \mathrm{C}$ in HBSS supplemented with $3 \mathrm{mg} / \mathrm{ml}$ of proteinase $\mathrm{K}$ and collagenase. The mixture was gently mixed by pipetting every $15 \mathrm{~min}$. The gastric mucosa cells were harvested by centrifugation for $15 \mathrm{~min}$ at $150 \times g$ and washed twice with PBS. The final suspension of the cells was adjusted to $10^{6}$ per ml with HBSS and further processed.

\section{Cell treatment}

HCAs were added from their $1 \mathrm{M}$ DMSO solution to the cell suspension to give final concentrations $0.05-0.15 \mathrm{mM}$. The control cells received only the growth medium with the chemical vehicles supplementation (DMSO and/or methanol). The final concentrations of DMSO and methanol were adjusted to the identical level in all samples. To examine DNA damage cells were incubated with HCAs for $1 \mathrm{~h}$ at $37^{\circ} \mathrm{C}$. Each experiment included a positive control, which was hydrogen peroxide at $10 \mu \mathrm{M}$ for $15 \mathrm{~min}$ on ice, producing a pronounced DNA damage in the gastric mucosa cells. To assess the effect of vitamin $\mathrm{C}$ and melatonin on DNA damage, cells were preincubated with vitamin $\mathrm{C}$ at $50 \mu \mathrm{M}$ or melatonin at $10 \mu \mathrm{M}$ for $30 \mathrm{~min}$ and incubated with IQ, PhIP and MelQx at $50 \mu \mathrm{M}$. Vitamin C was taken from a stock solution in water $(20 \mathrm{mM})$. Melatonin was derived from a stock $(10 \mathrm{mM})$ solution in methanol. The chemicals vehicles, DMSO and methanol, at the concentrations presented in the samples, did not affect the processes under study (data not shown).

\section{Comet assay}

The comet assay was performed under alkaline conditions essentially according to the procedure of Singh et al. [11] with modifications [12] as described previously [13].

\section{Data analysis}

The values in this study were expressed as mean \pm SEM from three experiments, i.e. the data from three experiments were pooled and the statistical parameters were calculated. Prior to statistical analysis we have used a normality test (Kolmogorov-Smirnov) to check that the two populations follow a normal distribution. The MannWhitney test was used to determine differences between samples with distribution departing from the normality. The differences between samples with the normal distribution were evaluated by the Student's $t$ test. Data analysis was performed using SigmaStat software (v. 3.0.0, SPSS, Chicago, USA).

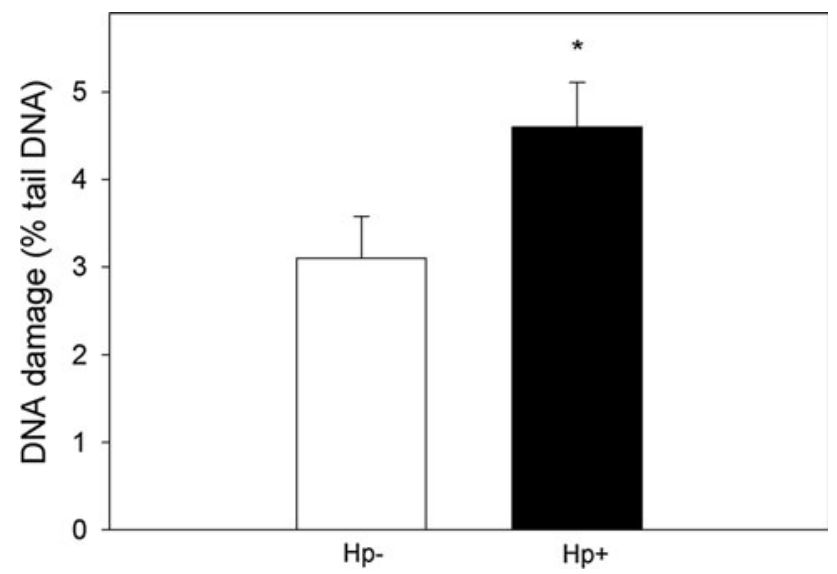

Fig. 1 Basal endogenous DNA damage measured as the mean comet tail DNA in alkaline comet assay of $H$. pylori-infected (white column) and non-infected (black column) gastric mucosa cells. 17 individuals were analyzed in the infected group and 23 in the non-infected (control) group. The number of cells scored for each individual was 50 and the analysis was repeated three times. Error bars denote SEM, $* p<0.05$, as compared with the non-infected cells

\section{Results}

Helicobacter pylori-infected gastric mucosa cells display a higher level of basal endogenous DNA damage than their non-infected counterparts

The mean basal endogenous DNA damage detected by the alkaline comet assay, measured as \% tail DNA in gastric mucosa cells of $H$. pylori-infected and non-infected patients is displayed in Fig. 1. The extent of DNA damage in $H$. pylori-infected patients was greater than in the noninfected ones $(p<0.05)$.

\section{IQ, PhIP and MeIQx induce DNA damage}

Figure 2 shows DNA damage measured in the alkaline version of the comet assay in $H$. pylori infected and noninfected human gastric mucosa cells exposed for $1 \mathrm{~h}$ to IQ, $\mathrm{PhIP}$ and MeIQx at 50, 100 and $150 \mu \mathrm{M}$. Single and double DNA strand breaks as well as alkali labile sites can be detected in this version of the technique. All HCAs induce a concentration dependent increase in the percentage of DNA in the comet tail $(p<0.001$ for each concentration). The extent of DNA damage was higher in $H$. pylori infected than in non-infected gastric mucosa cells $(p<0.05)$.

Vitamin $\mathrm{C}$ and melatonin protect gastric mucosa cells against the DNA-damaging effect of HCAs

Both vitamin $\mathrm{C}$ and melatonin exerted a protective effect; the effect was more pronounced in the infected cells (relative ratio of DNA damage without and with vitamin $\mathrm{C}$ in 


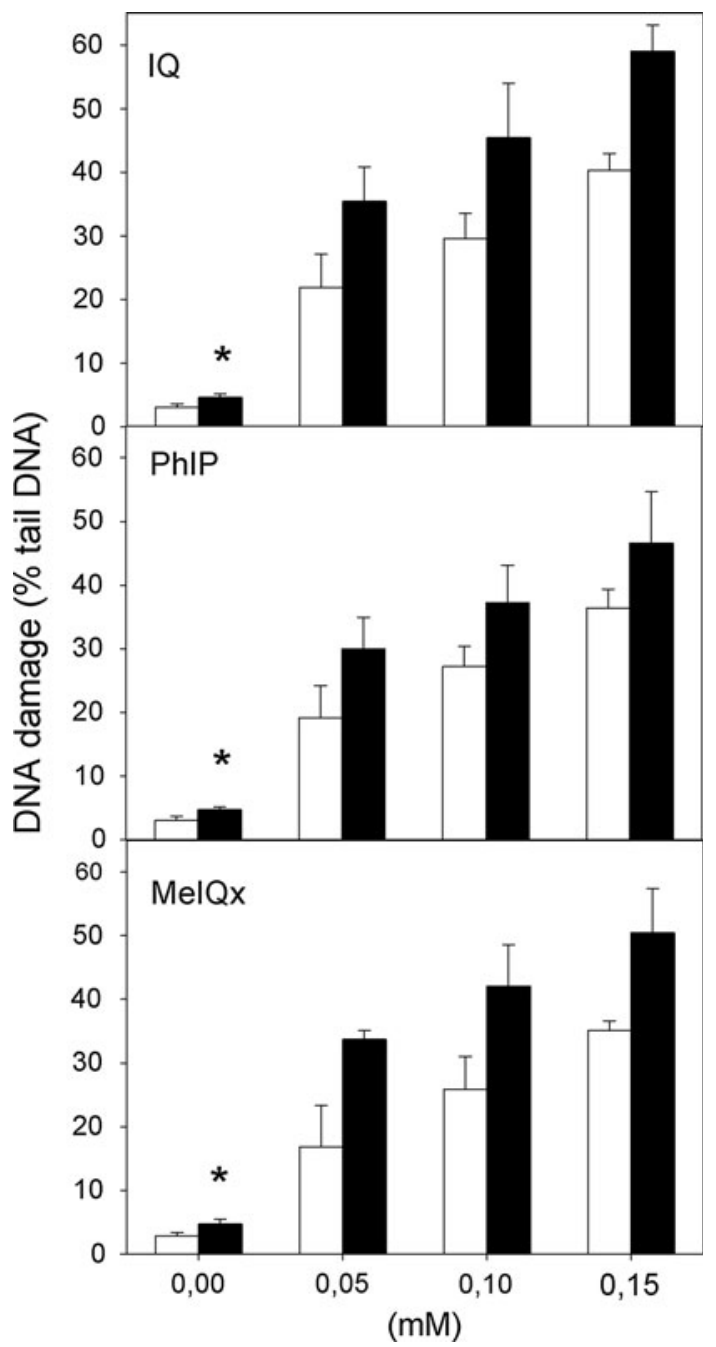

Fig. 2 DNA damage measured as the percentage of DNA in the tail of a comet in the alkaline comet assay of $H$. pylori-infected (black column) and non-infected (white column) gastric mucosa cells exposed for $1 \mathrm{~h}$ at $37{ }^{\circ} \mathrm{C}$ to 2-amino-3-methylimidazo[4,5-f]quinoline (IQ), 2-amino-1-methyl-6-phenylimidazo[4,5-b]pyridine (PhIP) and 2-amino-3,8-dimethyl-imidazo 4,5-f]quinoxaline (MeIQx). 17 individuals were analyzed in the infected group and 23 in the non-infected (control) group. The number of cells scored for each individual was 50 and the analysis was repeated three times. Error bars denote $\mathrm{SEM}, * p<0,001$

infected cells-2.32, in non-infected-4.11, $p<0.01$; Fig. 3). They also showed that the repair of the DNA damage induced by HCAs is faster in the infected cells (3.10 versus $2.53, p<0.05$, Fig. 4 ).

Helicobacter pylori-infected gastric mucosa cells display a faster initial kinetics of the repair of DNA damage induced by HCAs than their non-infected counterparts

We analyzed the kinetics of DNA repair in gastric mucosa cells after HCAs treatment by measuring the extent of

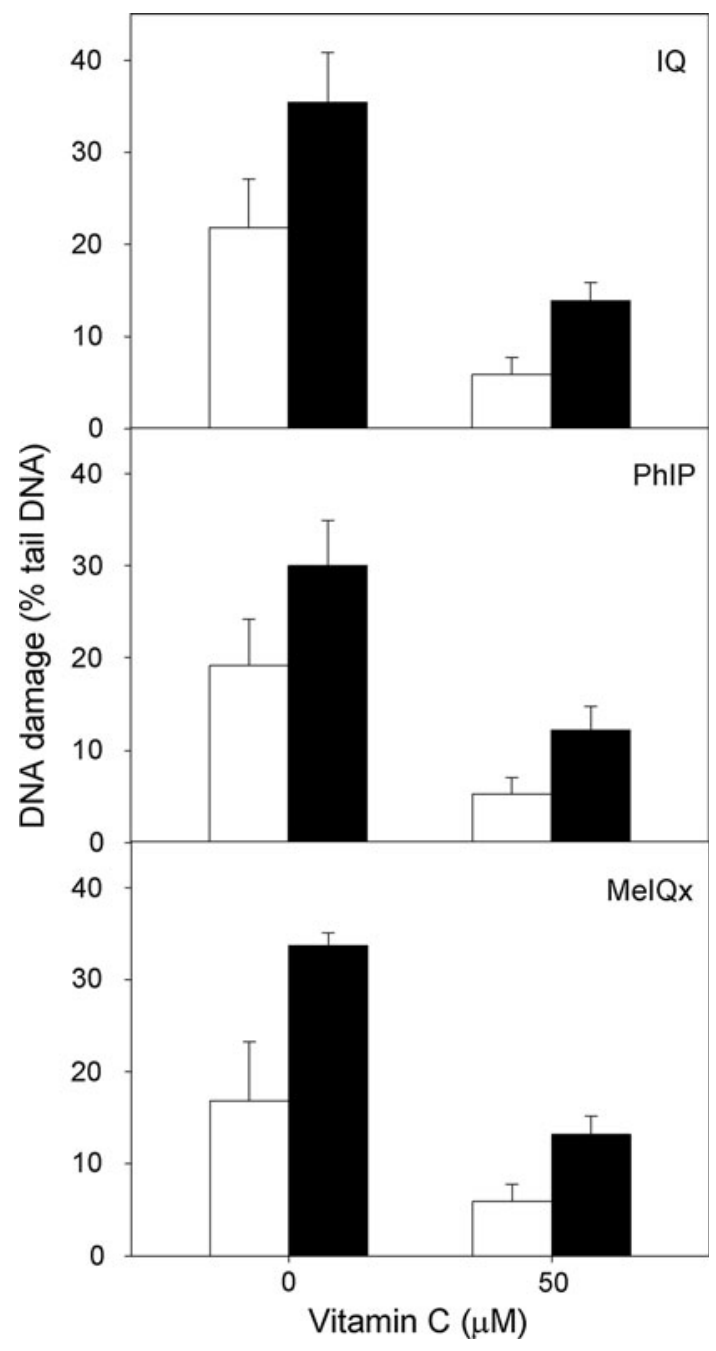

Fig. 3 DNA damage measured as the percentage of DNA in the tail of a comet in the alkaline comet assay of $H$. pylori-infected (black column) and non-infected (white column) human gastric mucosa cells exposed for $1 \mathrm{~h}$ at $37{ }^{\circ} \mathrm{C}$ to 2-amino-3-methylimidazo[4,5-f] quinoline (IQ), 2-amino-1-methyl-6-phenylimidazo[4,5-b]pyridine (PhIP) and 2-amino-3,8-dimethyl-imidazo 4,5-f]quinoxaline (MeIQx) after preincubation with vitamin $\mathrm{C}$ at $50 \mu \mathrm{M} .17$ individuals were analyzed in the infected group and 23 in the non-infected (control) group. The number of cells scored for each individual was 50 and the analysis was repeated three times. Errors bars denote SEM, $* p<0.01$

DNA damage in the cells exposed to either HCA at $50 \mu \mathrm{M}$ immediately after the exposure as well as 60,120 and 180 min thereafter (Fig. 5). The comet tail DNA of the control cells was constant, indicating that preparation and subsequent processing of the cells did not introduce a significant damage to their DNA. The cells exposed to $10 \mu \mathrm{M}$ hydrogen peroxide (positive control) were able to recover within $60 \mathrm{~min}$ (results not shown). The cells exposed to IQ, PHiP and meIQx at $50 \mu \mathrm{M}$ were able to remove more than $90 \%$ of the damage to their DNA within $180 \min (p<0.001)$. The character of the kinetics of DNA repair was similar in the infected as non-infected gastric 


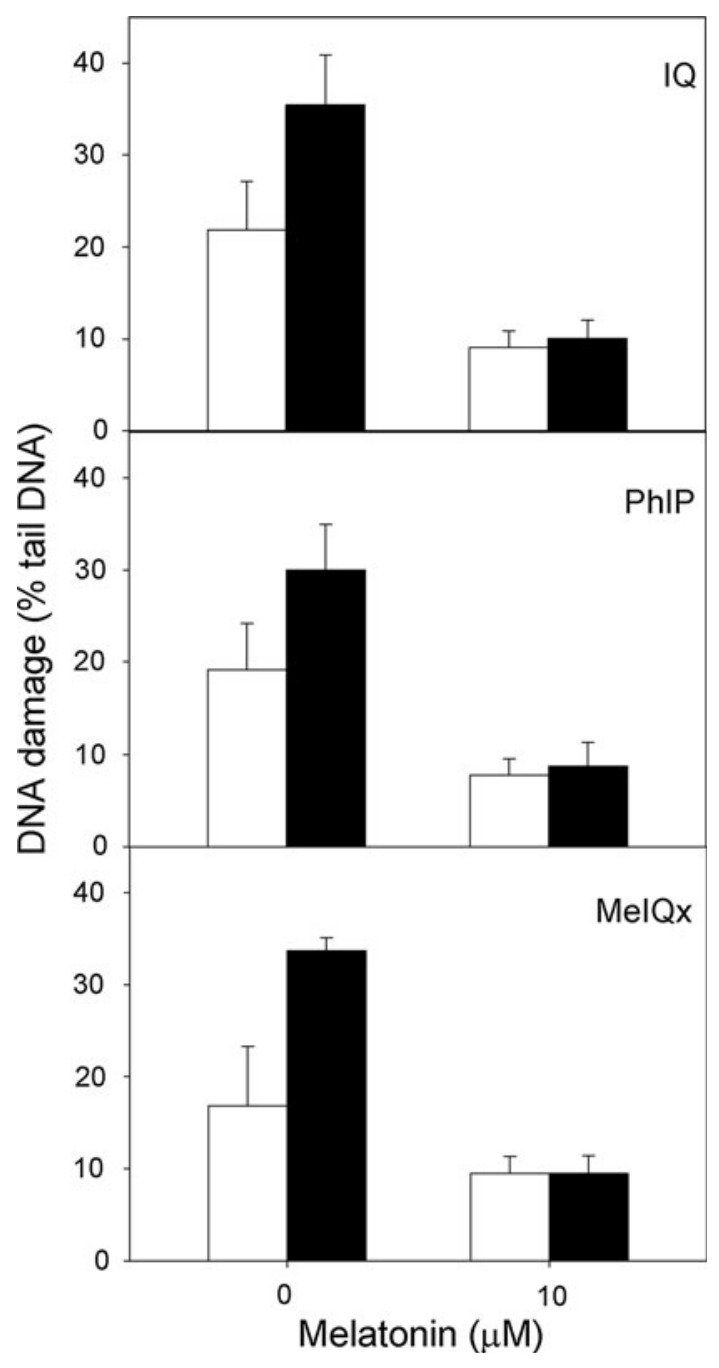

Fig. 4 DNA damage measured as the percentage of DNA in the tail of a comet in the alkaline comet assay of $H$. pylori-infected (black column) and non-infected (white column) human gastric mucosa cells exposed for $1 \mathrm{~h}$ at $37{ }^{\circ} \mathrm{C}$ to heterocyclic amines: 2-amino-3-methylimidazo[4,5f]quinoline (IQ), 2-amino-1-methyl-6-phenylimidazo[4,5-b]pyridine (PhIP) and 2-amino-3,8-dimethyl-imidazo 4,5-f]quinoxaline (MeIQx) after preincubation with melatonin at $10 \mu \mathrm{M}$. 40 individuals were analyzed in the infected group and 23 in the non-infected (control) group. The number of cells scored for each individual was 50 and the analysis was repeated three times. Errors bars denote SEM, $* p<0.05$

mucosa cells, but the former displayed a faster kinetics during approximately the first $60 \mathrm{~min}$ because at this timepoint, the extent of DNA damage in both kinds of cells did not differ significantly $(p>0.05)$ and remained the same till the end of the repair incubation.

\section{Discussion}

Helicobacter pylori infection induce the generation of intracellular ROS in gastric epithelial cells [14]. During

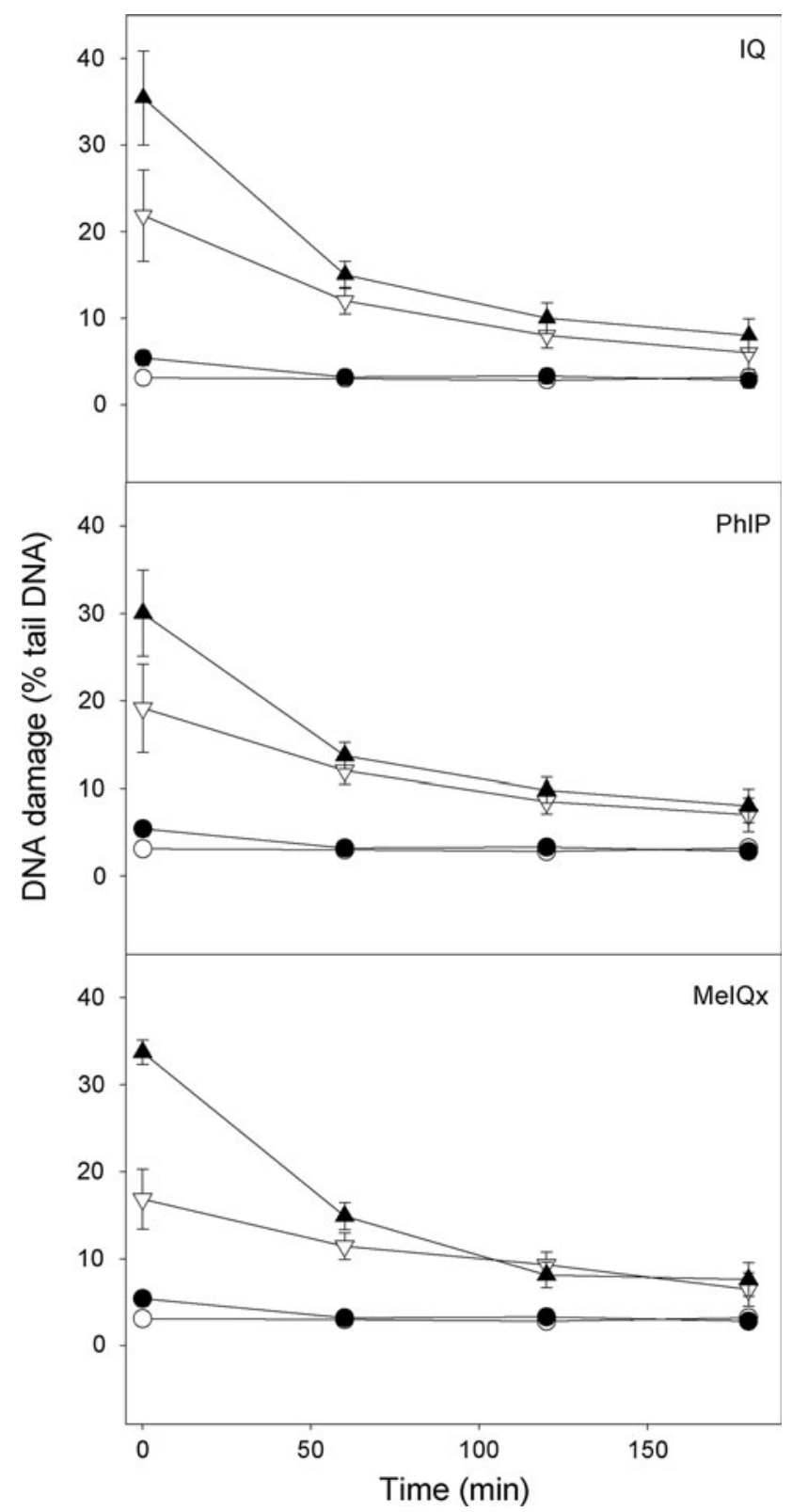

Fig. 5 The time course of the repair of DNA damage measured as the percentage of DNA in the tail of comets in the alkaline comet assay in Helicobacter pylori-infected (black) and non-infected (white) gastric mucosa cells treated (triangles) for $1 \mathrm{~h}$ at $37{ }^{\circ} \mathrm{C}$ to heterocyclic amines: 2-amino-3-methylimidazo[4,5-f]quinoline (IQ, A), 2-amino1-methyl-6-phenylimidazo[4,5-b]pyridine (PhIP, B) and 2-amino-3,8dimethyl-imidazo 4,5-f]quinoxaline (MeIQx, C). Cells were treated with a chemical, washed and incubated in a repair, heterocyclic amine-free, medium for $3 \mathrm{~h}$ at $37^{\circ} \mathrm{C}$. Untreated cells (dots) served as controls. 40 individuals were analyzed in the infected group and 23 in the non-infected (control) group. The number of cells scored for each individual was 50 and the analysis was repeated three times. Error bars denote SEM

this infection the host organism switches on an immune response associated with a considerable amount of free radicals and other harmful compounds. Independently of 
this response, some strains of the bacterium may produce the CagA protein, which may affect the stability of the gastric mucosa cells. Both phenomena may contribute to cancer transformation in the gastric mucosa. In the present work we wanted to assess, whether $H$. pylori infection may modulate the response of gastric mucosa cells to dietary mutagens, HCAs, and whether the infection affect also the action of known free radicals scavengers, vitamin $\mathrm{C}$ and melatonin. We have chosen $1 \mathrm{~h}$ incubations of gastric cells with HCAs, because food did not lie heavy on the stomach and the exposition time on food derived mutagens is relative short as compared with colon. Our results indicate that infection of $H$. pylori might increase the susceptibility of human gastric cells to HCAs. If we think about the mechanism of the interaction of a chemical with cellular DNA, firstly we should ask a question about the permeability of the plasma membrane to this chemical. In fact, urease, an enzyme of $H$. pylori, produces ammonia, which may destabilize the integrity of gastric mucosa cells membrane by the activation of neutrophils production, accelerated by free radicals produced by $H$. pylori and host immune cells [15]. Another mechanism of the changes in the permeability of the gastric mucosa cells membrane is associated with vacuolating cytotoxin (VacA) protein produced by $H$. pylori. VacA can cause a wide range of alterations in eukaryotic cells in vitro. VacA has the ability to induce the formation of large cytoplasmic vacuoles and permeabilization of the plasma membrane [16, 17], reduction of the mitochondrial transmembrane potential and release of cytochrome $\mathrm{c}$ from the mitochondrium $[18,19]$, inhibition of the activation and proliferation of $\mathrm{T}$ lymphocytes [20], and activation of mitogen-activated protein kinases [21]. Many cellular effects of VacA are attributed to the insertion of VacA into the membrane and the formation of membrane channels [22]. VacA was also reported to reduce the level of cellular glutathione (GSH) [23]. As a major route for the detoxification of HCAs metabolites per se is by their reaction with GSH. H. pylori decreases the ratio of HCAs utilization in gastric cells and consequently increase the time of action of reactive HCAs metabolites [24].

The main route of metabolic activation of HCAs includes oxidation to hydroxylamines, primarily by CYP1A2 but also by other CYP isoforms. HCAs are also substrates for NAT2 enzyme [25]. Expression of these enzymes was observed in gastrointestinal tract tissues including stomach, so stomach cells metabolize HCAs [26, 27]. There was no data suggesting the role of $H$. pylori (if any) on deregulations of cellular enzymes that metobolize HCAs. Our result might suggest that enhanced toxicity of HCAs in $H$. pylori infected gastric mucosa cells in comparision to non-infected cells was caused by higher rate of metabolic activation of HCAs in presence of $H$. pylori, but this hypothesis needs further studies. These studies should include CYP isoforms and NAT2 enzymes expression profile analysis in $H$. pyloriinfected and non-infected gastric cells and phenotype genotype correlation study with most common clinical associated SNP polymorphism of CYP and NAT2 enzymes. Our results show a significantly higher susceptibility of $H$. pylori-infected than non-infected gastric mucosa cells to HCAs, which is in general agreement with those reported by our group previously and Ladeira et al. [3, 28, 29]. On the other hand Everett et al. [30] showed that $H$. pylori infection decreased the extent of DNA damage observed in gastric mucosa cells. This is not in contrary to our results, since we investigated the induced extent of DNA damage. Moreover, we showed, that the in the first 60 min the infected cells repair their DNA with a faster kinetics than non-infected.

Our results show that DNA lesions induced by HCAs may be reduced by melatonin and vitamin C. Antioxidants levels used in this study correspond to concentrations observed in the gastric juice [31, 32]. Our previous studies have shown that use higher concentrations of this substances lead to DNA damage that is visible in comet assay [3]. Melatonin is a scavenger of a number of reactive oxygen and nitrogen species, and has an ability to reduce lipid peroxidation and may be used as a preventive antioxidant/free radicals scavenger [33]. Moreover, melatonin display some favorable effects in the gastrointestinal tract and can be used as an auxiliary drug in the treatment of some diseases of the tract [34]. The molecular mechanism of a protective action of melatonin in our experiment may be, at least in part, explained by its anti-inflammatory properties. Because melatonin may increase the concentration of GSH in the cell and regulate the activity of several enzymes involved in the detoxification process, it is therefore possible that it may eliminate the GSH-reducing effect of VacA in gastric cells $[35,36]$. Our data showing a better protective effect against DNA lesions induced by HCAs in H. pylori infected than non-infected cells support this hypothesis.

We observed that vitamin $\mathrm{C}$ decreased the extent of DNA lesions induced by HCAs in a $H$. pylori infection-dependent manner. Our data are in general agreement with those showing that vitamin $\mathrm{C}$ decreased mutation frequency induced by HCAs in rats [37]. It seems that the vitamin C may influence in some extent the metabolism of HCAs in rodents cells, because the results of other study performed on Salmonella typhimurium did not confirm the protective effect of vitamin $\mathrm{C}$ on DNA damage induced by HCAs.

HCAs are mutagens that are formed during the cooking of protein-rich foods such as meat or fish. Since these products are common in the diet worldwide, it is important to decrease their potential harmful consequences. Our results suggest that vitamin $\mathrm{C}$ and melatonin can be beneficial in this respect, but people infected with $H$. pylori 
should avoid taking food with HCAs, because the infection may potentiate the genotoxic action of these compounds, and such an action may sponsor cancer transformation of the gastric mucosa cells.

Acknowledgments The authors would like to thank Sylwia Smusz for her assistance.

Open Access This article is distributed under the terms of the Creative Commons Attribution License which permits any use, distribution, and reproduction in any medium, provided the original author(s) and the source are credited.

\section{References}

1. Schistosomes, liver flukes and Helicobacter pylori. IARC Working Group on the Evaluation of Carcinogenic Risks to Humans. IARC Monogr Eval Carcinog Risks Hum 61:1-241 (1994)

2. Correa P (2003) Helicobacter pylori infection and gastric cancer. Cancer Epidemiol Biomarkers Prev 12:238-241

3. Arabski M, Kazmierczak P, Wisniewska-Jarosinska M, Morawiec Z, Morawiec-Bajda A, Blasiak J (2006) Helicobacter pylori infection can modulate the susceptibility of gastric mucosa cells to MNNG. Cell Mol Biol Lett 11:570-578

4. Izzotti A, Durando P, Ansaldi F, Gianiorio F, Pulliero A (2009) Interaction between Helicobacter pylori, diet, and genetic polymorphisms as related to non-cancer diseases. Mutat Res 667: 142-157

5. Sugimura $T$ (1997) Overview of carcinogenic heterocyclic amines. Mutat Res 376:211-219

6. Felton JS, Malfatti MA, Knize MG, Salmon CP, Hopmans EC, Wu RW (1997) Health risks of heterocyclic amines. Mutat Res 376:37-41

7. Turesky RJ, Constable A, Richoz J, Varga N, Markovic J, Martin MV, Guengerich FP (1998) Activation of heterocyclic aromatic amines by rat and human liver microsomes and by purified rat and human cytochrome P450 1A2. Chem ResToxicol 11:925-936

8. Turesky RJ, Rossi SC, Welti DH, Lay JO, Kadlubar FF (1992) Characterization of DNA adducts formed in vitro by reaction of $\mathrm{N}$-hydroxy-2-amino-3-methylimidazo[4,5-f]quinoline and $\mathrm{N}$ hydroxy-2-amino-3,8-dimethylimidazo[4,5-f]quinoxaline at the C-8 and N2 atoms of guanine. Chem Res Toxicol 5:479-490

9. Layton DW, Bogen KT, Knize MG, Hatch FT, Johnson VM, Felton JS (1995) Cancer risk of heterocyclic amines in cooked foods: an analysis and implications for research. Carcinogenesis $16: 39-52$

10. Felton JS, Knize MG, Shen NH (1986) The isolation and identification of a new mutagen from fried ground beef: 2-amino-1methyl-6-phenylimidazo[4,5-b]pyridine (PhIP). Carcinogenesis 7:1081-1086

11. Singh NP, McCoy MT, Tice RR, Schneider EL (1998) A simple technique for quantification of low levels of DNA damage in individual cells. Exp Cell Res 17:84-191

12. Klaude M, Eriksson S, Nygren J, Ahnstrom G (1996) The comet assay: mechanisms and technical considerations. Mutat Res 363: 89-96

13. Poplawski T, Pawlowska E, Wisniewska-Jarosinska M, Ksiazek D, Wozniak K, Blasiak J (2009) Cytotoxicity and genotoxicity of glycidyl methacrylate. Chem Biol Interact 180:69-78

14. Ding S, Minohara Y, Fan XJ, Wang J, Reyes VE, Patel J, DirdenKramer B, Boldogh I, Ernst PB, Crowe SE (2007) Helicobacter pylori infection induces oxidative stress and programmed cell death in human gastric epithelial cells. Infect Immun 75/8: 4030-4039

15. Suzuki M, Miura S, Suematsu M, Fukumura D, Kurose I, Suzuki H, Kai A, Kudoh Y, Ohashi M, Tsuchiya M (1992) Helicobacter pylori-associated ammonia production enhances neutrophil-dependent gastric mucosal cell injury. Am J Physiol Gastrointest Liver Physiol 263:719-725

16. Czajkowsky DM, Iwamoto H, Cover TL, Shao Z (1999) The vacuolating toxin from Helicobacter pylori forms hexameric pores in lipid bilayers at low $\mathrm{pH}$. Proc Natl Acad Sci USA 96:2001-2006

17. Szabo I, Brutsche S, Tombola F, Moschioni M, Satin B, Telford JL, Rappuoli R, Montecucco C, Papini E, Zoratti M (1999) Formation of anion-selective channels in the cell plasma membrane by the toxin VacA of Helicobacter pylori is required for its biological activity. EMBO J 18:5517-5527

18. Galmiche A, Rassow J, Doye A, Cagnol S, Chambard JC, Contamin S, de Thillot V, Just I, Ricci V, Solcia E, Van Obberghen E, Boquet P (2000) The N-terminal $34 \mathrm{kDa}$ fragment of Helicobacter pylori vacuolating cytotoxin targets mitochondria and induces cytochrome c release. EMBO J 19:6361-6370

19. Willhite DC, Blanke SR (2004) Helicobacter pylori vacuolating cytotoxin enters cells, localizes to the mitochondria, and induces mitochondrial membrane permeability changes correlated to toxin channel activity. Cell Microbiol 6:143-154

20. Gebert B, Fischer W, Weiss E, Hoffmann R, Haas R (2003) Helicobacter pylori vacuolating cytotoxin inhibits $\mathrm{T}$ lymphocyte activation. Science 301:1099-1102

21. Nakayama M, Kimura M, Wada A, Yahiro K, Ogushi K, Niidome T, Fujikawa A, Shirasaka D, Aoyama N, Kurazono H, Noda M, Moss J, Hirayama T (2004) Helicobacter pylori VacA activates the p38/activating transcription factor 2-mediated signal pathway in AZ-521 cells. J Biol Chem 279:7024-7028

22. Cover TL, Blanke SR (2005) Helicobacter pylori VacA, a paradigm for toxin multifunctionality. Nat Rev Microbiol 3:320-332

23. Chitcholtan K, Hampton MB, Keenan JI (2008) Outer membrane vesicles enhance the carcinogenic potential of Helicobacter pylori. Carcinogenesis 29:2400-2405

24. Coles B, Nowell SA, MacLeod SL, Sweeney C, Lang NP, Kadlubar FF (2001) The role of human glutathione S-transferases (hGSTs) in the detoxification of the food-derived carcinogen metabolite N-acetoxy-PhIP, and the effect of a polymorphism in hGSTA1 on colorectal cancer risk. Mutat Res 482:3-10

25. Hengstler JG, Van der Burg B, Steinberg P, Oesch F (1999) Interspecies differences in cancer susceptibility and toxicity. Drug Metab Rev 31:917-970

26. Canturk P, Caner V, Oruc N, Akarca US, Tepeli E, Cetin OG, Zencir S, Topcu Z (2010) The mRNA expression of cytochrome P450 isoforms in human gastric tissue. Hepatogastroenterology 57:372-376

27. Windmill KF, Gaedigk A, Hall PM, Samaratunga H, Grant DM, McManus ME (2000) Localization of $N$-acetyltransferases NAT1 and NAT2 in human tissues. Toxicol Sci 54:19-29

28. Arabski M, Klupinska G, Chojnacki J, Kazmierczak P, Wisniewska-Jarosinska M, Blasiak J (2005) DNA damage and repair in Helicobacter pylori-infected gastric mucosa cells. Mutat Res 570:129-135

29. Ladeira MS, Rodrigues MA, Salvadori DM, Queiroz DM, FreireMaia DV (2004) DNA damage in patients infected by Helicobacter pylori. Cancer Epidemiol Biomarkers Prev 13:631-637

30. Everett SM, White KL, Drake IM, Schorah CJ, Calvert RJ, Skinner C, Stringer MD, Miller D, Dixon MF, Chalmers DM, Axon AT (2002) The effect of Helicobacter pylori infection on levels of DNA damage in gastric epithelial cells. Helicobacter 7:271-280 
31. Zhang ZW, Abdullahi M, Farthing MJG (2002) Effect of physiological concentrations of vitamin $\mathrm{C}$ on gastric cancer cells and Helicobacter pylori. Gut 50:165-169

32. Zhang ZW, Patchett SE, Perrett D, Katelaris PH, Domizio P, Farthing MJG (1998) The relation between gastric vitamin C concentrations, mucosal histology, and CagA seropositivity in the human stomach. Gut 43:322-326

33. Reiter RJ, Korkmaz A, Paredes SD, Manchester LC, Tan DX (2008) Melatonin reduces oxidative/nitrosative stress due to drugs, toxins, metals, and herbicides. Neuro Endocrinol Lett 29:609-613

34. Klupinska G, Poplawski T, Drzewoski J, Harasiuk A, Reiter RJ, Chojnacki J, Blasiak J (2007) Therapeutic effect of melatonin in patients with functional dyspepsia. J Clin Gastroenterol 41:270 274

35. Tomas-Zapico C, Coto-Montes A (2005) A proposed mechanism to explain the stimulatory effect of melatonin on antioxidative enzymes. J Pineal Res 39:99-104

36. Rodriguez C, Mayo JC, Sainz RM, Antolin I, Herrera F, Martín V, Reiter RJ (2004) Regulation of antioxidant enzymes: a significant role for melatonin. J Pineal Res 36:1-9

37. Montgomery BA, Murphy J, Chen JJ, Desai VG, McGarrity L, Morris SM, Casciano DA, Aidoo A (2002) Mutagenicity of foodderived carcinogens and the effect of antioxidant vitamins. Nutr Cancer 43:103-110 